\title{
Hermeneutics in identity formation: Paul's use of Genesis in Galatians 4
}

\begin{abstract}
Author:
Jeremy Punt ${ }^{1}$

Affiliation:

${ }^{1}$ Department of Old and

New Testament, University

of Stellenbosch, South Africa

Note:

This article is a revised version of a paper read at a Biblical Research Unit meeting, KU Leuven, September 2008. In Galatians 4:21-5:1 Paul's rereading of course went beyond that of Genesis, including also Isaiah (54:1), but the focus in this contribution will be on the use of Genesis 16 and 21 in Galatians 4; the contribution links up with earlier work on the text of Galatians 4 (cf. Punt; 2006a, 2006b, 2007).
\end{abstract}

\section{Correspondence to:} Jeremy Punt

email:

jpunt@sun.ac.za

Postal address:

Private Bag X1, Matieland 7602 , South Africa

Dates:

Received: 30 Apr. 2010 Accepted: 06 Aug. 2010 Published: 07 June 2011

How to cite this article: Punt, J., 2011, 'Hermeneutics in identity formation: Paul's use of Genesis in Galatians 4', HTS Teologiese Studies/ Theological Studies 67(1), Art. \#846, 9 pages. DOI: 10.4102/hts.v67i1.846

C) 2011. The Authors. Licensee: OpenJournals Publishing. This work is licensed under the Creative Commons Attribution License.
Paul's hermeneutics, in dealing with the scriptures and traditions of Israel and his concern for a specific identity for the communities he interacted with, require attention for the reciprocal, interrelationship between hermeneutics and identity in his letters. Paul's quotations from and allusions to the scriptures of Israel but also his argument which was a re-interpretation of the traditions of Israel, functions in Galatians 4:21-5:1 at one level as counter-argument to the position of his opponents in Galatia but, at another deeper level, also as a forceful attempt to (re)establish and reinforce the identity of the community of followers of Jesus. His appropriation of the scriptures, his revisionist interpretation of the Abraham narrative and in particular his construal of its lasting implications provided the interpretative map on which Paul plotted an emerging 'Christian' identity. But, reciprocally, Paul's sense of a new or renewed identity in Christ also determined the contours of his hermeneutics.

\section{Introduction}

Paul's letters urged the followers of Jesus to take up a new, reformatted identity, not as abstract ideal, but an identity closely connected to Paul's vision of a new community, establishing a reciprocal relationship between identity and community. ${ }^{1}$ In the Galatians letter, Paul's insistence upon a new identity and a resultant new community, was largely dependent on his appropriation of the scriptures and a central narrative within it, namely about Abraham, his wives and sons. Claims regarding a new identity proved troublesome to other Jews and Gentiles alike as is evident in Galatians, leading to tension, animosity and even conflict. The opposition and counter-claims Paul encountered after his departure from Galatia and addressed in the letter underwrote his resolve regarding his perceived need to promote a new identity in Christ - which he did in conjunction with the scriptures.

\section{Rereading Genesis}

\section{Genesis 16 and 21 in Galatians 4:21-5:1}

Galatians was written ${ }^{2}$ in the midst of what was understood by Paul as a major clash (probably one of many) between himself and those opposing his understanding of the lasting implications of Jesus' life and death. It was in particular the implications of Jesus for the Jewish people as well as for his followers' continuing relationship with the Jewish historical legacy, community and culture including religious belief, custom and ritual that provoked some animated argument in Paul's letters and in Galatians in particular.

The Galatians-letter is directed to communities of Jesus-followers in Asia Minor, but the letter suggests that the disagreement between Paul and his challengers took place within a, at least partially, Diaspora-Jewish context. ${ }^{3}$ A large part of Paul's argument in Galatians was formulated as scriptural proofs. ${ }^{4}$ In one instance in Galatians 4, Paul's contemporary if dissident rereading

1.The original Pauline emphasis was retained in the Eastern Church, where 'the problem of the relation of faith to works has never had such a central position. In the East, Christians regard Paul as a saint, a mystic and a martyr. As to his theology, his image of the church as the body of Christ was more important than his doctrine of justification' (Dahl 1977:20 [author's emphasis]). Georgi (1991:52ff) refers to 'the corporate identity of Christ'; cf. Hays (1996:32-36) for the 'fundamental emphasis on community in Paul's thought'. Broader, Martin (1994:117-140) questions the supposed individualist character of Hellenism.

2.Galatians is generally seen as one of Paul's undisputed or authentic letters, addressed to the early churches of the followers of Jesus found by the apostle in central Asia Minor or most central Anatolia (so Betz). It was most probably written in the early fifties (50 or $51 \mathrm{CE}$ ), although its provenance remains a puzzle: Ephesus, Macedonia, Corinth and even Rome have been suggested. Galatians is a short and confrontational letter, probably representing the early phase of a dispute with adversaries in the form of Jewish (or Jewishinspired) followers of Jesus (cf. also in Phlp 3:2-21; 2 Cor 10:1-13:10; Rm 16:17-20) relating to the relationship between theological issues and socio-political matters such as the identity of the community, within the context of 1st generation followers of Christ.

3.Although the Galatian converts were probably from Gentile stock (cf. $\mathrm{Gl} 4: 8$ ), they encountered a Jewish framework of understanding with Paul's earlier visit and in the mean time were apparently confronted by Judaisers (cf. Gl 2:14; false brothers in 2:4), or Gentile followers of Jesus insisting on complementing faith in Christ Jesus with Jewish custom and ritual (GI 1:6-7; 5:1-12; 6:12-13).

4.In Galatians 3:1-5:1, 5 scriptural proofs were provided: Galatians 3:6-9 (regarding Abraham); Galatians 3:10-14 (regarding the restoration of Israel's honour); 3:15-16/16-18 (regarding God's promises to Abraham); 3:17-22 (regarding relationship of God's promises to Abraham and God's law through Moses); 4:21-5:1 (regarding the wives and children of Abraham); cf. for example, Malina and Neyrey (2006:177-178). Paul used scriptural proofs together with his understanding of the Gospel as preached in Galatia (GI 1:6-9; and 16 ) (2006:177-178). Paulused scriptural proofs together wish his undering 
of the Genesis narrative (Gn 12-25), resulted in an alternative, allegorical interpretation, which challenged the notion that Jews belonged to the lineage of Abraham through their physical descent from Abraham and Sarah. Even more, in the end his rereading challenged the very notion of physical lineage, or, at least, using such determinations as basis for affiliation with Christ Jesus. The materiality of Abraham, his wives and sons are not discarded, but physicality as basis for establishing lineage has now been subverted (cf. Ebeling 1985:234; Martyn 1990:175).

Whilst 1st century hermeneutics cannot be discussed here in detail, it should be mentioned that Paul used the scriptures according to conventional 1st century hermeneutical practices which in short entailed that (cf. Punt 1996):

- the scriptures are holy and therefore should be interpreted

- are the living word of God and therefore remains actual for the lives of other generations as well

- that the scriptures can be interpreted by inspired, spiritfilled interpreters.

Regarding the notion of inspired interpreters, it needs to be noted that Paul's radical hermeneutical shift was dependent on a disposition of trust towards the interpreter and his expectation that the Galatian churches would accept him as faithful interpreter of the scriptures (cf. Fowl 1994:77-95; cf. Stanley 2004:130-135). Paul is confident that his tailor-made, allegorical interpretation can persuade his audience (Stanley 2004:130-135), that the narrative on the wives of Abraham in Genesis requires a counter-conventional reading, to say the least, ${ }^{5}$ which deconstructs and reconstructs Israel's history (cf. Janzen 1991:17). ${ }^{6}$ In essence, Paul's retelling of the origin of Abraham's children rests on a comparison of his two wives, ${ }^{7}$ Sarah and Hagar. ${ }^{8}$ Paul's sublime appeal to his readers is through his hermeneutical procedure in which Abraham and Sarah are treated as typical and normative examples, concentrating on scriptural texts which emphasised that Israel's special place with God is relativised (Dunn 1990:203). His reliance upon a scriptural argument constituted a very important element in Paul's efforts to establish a particular identity in Galatians.

\section{The 1st century CE and identity issues: Implications for Paul}

Three important considerations about identity in the 1st century $\mathrm{CE}$ deserve attention before the relationship between Paul's hermeneutics and concern with identity is addressed.

5.Paul's interpretation cannot be dismissed as evidence of a Hellenistic attitude and approach to the scriptures of Israel (pace Soards 1999:96).

6.Paul's sublime appeal is through his hermeneutical procedure in which the example of Abraham is treated as typical and normative, concentrating on scriptural texts which emphasise that Israel's special place with God is relativised (Dunn 1990:203).

7.Refer to Cyprian's Testimonia (1.20) for other instances of comparing wives: in the case of Jacob's 2 wives, Leah represents the synagogue and Rachel (mother of Joseph) the church; with Elkana's 2 wives the church is deemed to be symbolised by Hannah, mother of Samuel (and another messianic figure).

8.In Genesis 25:1 another wife is mentioned - Ketura - and the names of six sons Abraham had with her. Scholars differ about the nature of the claim (biographical or literary and the latter probably in order to associate certain peoples with Abraham), the chronology involved regarding its placement in the life of Abraham (e.g. before or after sending Hagar away in Gn 21) and so forth (cf. Wenham 1994).
Firstly, social identity theory is briefly presented as a useful explanation of the interplay between social groups, their sense of identity and, disagreement and conflict between groups. It is also argued that social identity theory may assist in understanding group- and identity configurations and tensions in Pauline texts. This is followed by a short review of important considerations regarding 1st century CE identity, all of which stood in the shadow of Empire.

\section{Social identity theory and 1st century identity}

Social identity theory (SIT) derives to a large extent from the work of social psychologist Henri Tajfel, ${ }^{9}$ who was inspired by issues of group prejudice, how judgement and behaviour of groups were influenced and distorted in a pervasive way and through complex mechanisms by social values; or, to put it differently, by the intricate relationship between human psychological functioning and large-scale social processes and events which affect and are affected by the former (cf. Turner 1996a:4). Social identity can be understood as:

that part of the individuals' self-concept which derives from their knowledge of their membership of a social group (or groups) together with the value and emotional significance attached to that membership.

(Tajfel 1982b:2)

The underlying notion of SIT is the belief that:

however rich and complex may be the individuals' view of themselves in relation to the surrounding world, social and physical, some aspects of that view are contributed by the membership of certain social groups or categories.

(Tajfel 1982b:2)

The concern is to understand the conditions within which individuals choose to identify themselves and act as members of a group, rather than in their individual capacity. Individuals often choose to define their social location according to selected group affiliations, due to processes of social influence which cause them to internalise certain social norms and to which they, in a variety of circumstances, consciously relate and model in their attitudes and social behaviour. What is important to acknowledge, however, is that such group identity is not dependent upon group cohesion or physical and direct interaction with other people, not even those associating with the same group (Tajfel 1982b:4; Turner 1982:15-40). People are part of a group because they choose to associate with the group - people actively engage in construing and constructing the world in which they live. ${ }^{10}$

9.A Polish-Jew who left Poland in 1937, studied in France (Universities of Toulouse and Paris, Sorbonne), fought for France during the Second Word War and spent from 1940-1945 in a POW camp and after doing upliftment work in post-War France and Germany, moved to the UK in 1951 (Turner 1996a:1-6). For a chronology and threefold taxonomy of his research (perceptual accentuation, categorisation and stereotyping; social identity and intergroup relations; social psychology and social context), cf. Turner (1996a:11-21)

10.Using social identity theory for explaining group identity and -behaviour in the 1st century CE, is not unproblematic and two concerns include: SIT is, notwithstanding its focus on social groups and their dynamics, ultimately directed towards explaining the individual; unlike 1st century CE collectivist or dyadic context. Secondly, SIT as theoretical point of departure fixes 'a spiral of conflict between groups from which it is not easy to see an escape' (Tajfel 1982a:483). The conceptual distance and epistemological determinacy created in using SIT heuristically in the analysis of ancient texts should be factored into such analysis. 


\section{Identity concerns in the 1st century CE}

Typical of the surrounding biblical antiquity of the 1st century CE, the New Testament texts offer no clearly defined concept of personhood. With the ascription of personhood to angelic beings, demons and the personification of evil in the form of the devil and even to the divine, it is clear that the New Testament authors applied different criteria for what constituted a person and so went beyond the modern perception of human beings as embodied psyches and therefore persons (Berger 2003:2629). Paul's notion of identity and resulting boundaries are best plotted on the 1st century map of identity-concerns, which were influenced by dyadism, or an other-directed orientation (Neyrey 1993:49-52). As group-oriented, collectivist people in a non-introspective culture, the in-group provided the means by which people understood themselves and others:

In-group members are treated with loyalty, openness, allegiance and support. Those falling outside the in-group boundaries belong to the out-group. With the out-group, dealings are indifferent, even hostile.

(Malina \& Neyrey 1996:122)

Nevertheless, a deterministic appropriation of such categories such as assuming a monolithic or homogenous constitution within groups has to be avoided, though, because the ingroup boundaries were uneven and of differing qualities.

The strong sense of identity in a collectivist or grouporiented culture and continuous efforts to maintain and elaborate on it, necessarily required demarcation as much as identification. In other words, it was at least as important to define a group over against or in terms of other groups as was the concern with self-identity (and reflection upon it). However, constructing borders between people and us-and-them binaries was within the 1st century, agonistic society not seen as complimentary, as the New Testament documents attest: opposites led to competition and at times called forth hostilities. Hostility and even violence was natural in the 1st century Mediterranean context (Botha 2000:8-18), because aggression in different forms was common in an agonistic society ${ }^{11}$ and part of everyday life, the extent to which emerges even from a brief analysis of the New Testament vocabulary..$^{12}$ Identity issues were therefore generally perilous and fraught with danger, as reflected in Paul's fluctuating fortunes in the Corinthian correspondence encompassing a few years' interaction.

\section{Identity in an imperial context}

Paul's assumption of a position of defining and controlling identity has to be understood against the context of an all-

11.The exercise of power meant the ability to exert control over the behaviou of others and so power was a highly rated means value and thus a value which facilitated the achievement of core and secondary values (Pilch 1993:139-143).

12.The vocabulary for conflict in the New Testament is varied, including physical human violence, the cosmic struggle between good and evil and (metaphorically) the Christian's life of service to God as a spiritual battle; however, military term dominate, indicative of the military environment of the day (Desjardins 1997:63$64)$. On the other hand, the failure to address social justice issues and an emphasis on 'peace' that does not allow for resistance against physical oppression, can also be considered violence (Desjardins 1997:34). Scholars has shown in the past how for some philosophers such as Freud, Girard and Lacan, violence and identity formation are intertwined, given the need to establish one's own identity through the annihilation of the identity of the Others (cf. Kelso 2008:2). pervasive Roman Empire, where the social and political standing of Jews in relation to the followers of Jesus was an important factor in their relationship. In the 1st century CE, the Jews were at times permitted certain concessions, which allowed them to maintain their customs and beliefs, ${ }^{13}$ so that they, notwithstanding occasional outbreaks of violence against them, ${ }^{14}$ generally flourished during imperial times. As long as the early followers of Jesus still associated with Judaism, they shared in these privileges, but as the divisions grew, emerging Christianity had to find other ways to present itself as a legal and respectable religion, ${ }^{15}$ inevitably resulting in tensions and conflict with Judaism. Firstly, because heritage and longevity mattered most in the defense of a religion, the New Testament authors and the early followers of Jesus, in their search for an ancient and respectable pedigree, claimed to be the new (or better), renewed and thus true, Israel (e.g. Rm 9-11; Eph 2:12; Heb 8 ; Jn 15:1). Secondly and flowing from this, the early Jesusfollowers' increasing concern with their identity and selfdefinition, consciously and increasingly distinguished themselves from the Jews. And thirdly, competing with the Jews for the sympathies of and associates from the gentiles, the Jewish communities which were larger in size were viable competitors, a source of embarrassment for 'Christian' claims and a potential threat to the growth of communities of followers of Jesus. ${ }^{16}$ However, relaxed 'border-control' in the 1st century would have facilitated congenial relationships between Jews and non-Jews, ${ }^{17}$ with such interaction probably stimulating progress in mutual acceptance of (Jewish and non-Jewish) bona fides. ${ }^{18}$

SIT emphasises that individuals and groups generally do not have equal access to power and it is important to distinguish between and account for the differences between groups

13.For example, exemption from military duty and the emperor cult, the right to keep the Sabbath and to collect the temple tax.

14.Such animosity mainly came from the Roman intelligentsia and the violence caused by localised tensions and it was the Jewish success in attracting both converts and sympathisers that often aggravated Roman antipathy (Wilson 1992:835).

15.As the Acts of the Apostles and later also, for example, Diognetus and Origen showed (Diogn. 1-3; Or. Cels. 2.1, 2.4), early Christianity had to defend itself against accusations of being little more than a novel superstition, unwilling to participate in other religious activities of the day.

16.With growing levels of animosity, the likelihood of early Christians suffering Jewish harassment increased and is probably reflected to some extent in Acts and mentioned by Justin (Apol. 1.31.6; Wilson 1992:835). After the destruction of the temple in 70 CE the tension between Jewish religious and Jewish national identity reached breaking point (Davis 2007:235).

17.Tracing the identity concerns of Paul in this context, the view of FC Baur regarding the universality of Christianity versus the exclusivity of Judaism often still rules. Dunn (1988:72) claims that Paul saw the us-over-against-them attitude as 'the heart of the Jewish failure and as a potential danger for Gentile Christians' and that it should therefore not become typical of the eschatological people of God (cf. also Volf 1996:43-50). Paul's views were seen as both the result of and contributing to Volf 1996:43-50). Paul's views were seen as both the result of and contributing to
the opposition between the particularist elements and claims of 1 st century Jewish the opposition between the particularist elements and claims of 1st century Jewish
groups and the universalistic if smaller 'Christian' groups. His shift from Judaism to Christianity was seen as initiated by the Damascus-road events and thus as a move 'from the bodiliness of genealogy to the pure spirituality of faith, from the particularity of "peoplehood" to the universality of multiculturality, from the locality of land to the globality of the world' (Volf 1996:43-50). In his argument, Volf aligns himself with Boyarin (although Boyarin criticises the coercive 'universalising' or multicultural transformation of Jewish tradition, cf. Boyarin 1994:228-260) and subscribes to Dunn's thesis that Paul's law-polemic addressed Jewish nationalism and ethnocentrism, believed to exclude Gentiles from a covenantal relationship with God.

18.Amidst imperial pressures, 1 st century boundary lines between Jewish and nonJewish identity were flexible and even blurred (Bij de Vaate and Van Henten 1996:28) and Paul's notions of difference and of Others are not adequately captured by a rigid and Paul's notions of difference and of Others are not adequately captured by a rigid
'Jew-Christian' contrast: Paul was a Jew and proud of it (e.g. 2 Cor 11:22; Phpl 3:5; $\mathrm{Rm}$ 11:1-2). 
dominating others and those groups who are being or were dominated:

Members of dominating groups are often capable of imposing a view of the world in which the norm or the point of reference in relation to which other people are defined come form the centre where the power resides.

(Tajfel 1982bb:5; cf. Deschamps 1982:85-98)

This situation is the opposite of those belonging to the powerful groups and those who are often not defined in terms of their groups but simply as individuals:

The social categorizations imposed upon those who are peripheral or dominated groups account for much of the way in which they define themselves and are defined by others. The achievement or the construction for oneself of full individuality is the privilege of social differentials

(Tajfel 1982bb:5; cf. Deschamps 1982:85-98)

In the New Testament, the Pauline letters in particular suggest continuing efforts by various groups and by Paul none the least, to establish religious and socio-political control by insisting on strict lines of demarcation. The hegemony of imperialism, which also penetrated into Galatians 4, underlined Paul's 1st century context as an imperial setting but also one where there would not be room enough for Paul and Roman authority, leading to Paul's ambiguous attitude towards the Roman Empire. But Paul's concern with imperialism goes beyond Rome and political matters in the narrow sense of the word, as reflected in his concerns with religious hierarchy as, for example, in his interaction with the 'pillar' apostles and Jerusalem, the custodian of the law and his recounting of his discussion with Peter in Galatians 1 and 2. At yet another level, competition and rivalry are present also in the Galatian-context in what seems to have been an acrimonious conflict between Paul and other rival groups and the 'Judaisers' by name.

Amidst the broader vying for power to define the identity of the followers of Jesus, Paul's rereading of foundational texts constituted an important element is his particular way of formulating and advocating a new identity in Christ Jesus - at least for the groups he dealt with; this is also evident in Galatians 4:21-5:1.

\section{Reconstituted identity and the role of hermeneutics}

His letters and certainly Galatians provide no evidence of a consistent concern on Paul's side that he consciously endeavoured to produce a history of some sort ${ }^{19}$ (at least not in the sense that history would be understood today), whether of the life of Jesus, his own life (and that of his people), or of the followers of Jesus (the 'church'). ${ }^{20}$ On the one hand, it is in

19.Not even in the sections in his letters where he deals with historical matters, such as, for example, Romans 9-11. The attempts to enlist Paul's support for a salvation history unfortunately often amounts to little more than theological cooptation and offers a construal of Paul's thought that do not always adequately deal with how Paul in his letters interacted with and configured history.

20.The indications are rather that Paul consciously interacted with the identity concerns of the Galatian audience, which his remark in Galatians 4:21 (oi Uंmo

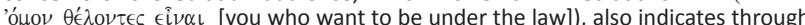
emphasising their volition and choice for a certain modality of existence, 'under emphasising
Galatians that Paul devoted most attention to and the largest part of any single letter that included an autobiographical account (G1 1-2). It is therefore not altogether surprising to find Paul in Galatians 4:21-5:1 retelling in broad strokes the story of the wives of Abraham, even if in a format foreign to 1st century concerns (with the focus on Abraham's wives and not the patriarch himself) and in a register not uncommon for the time (Septuagint quotes were strung together with prophetic material and his own additions and explanations). From a literary perspective:

History is 'fictional', not in the sense of something false but in the sense of something produced in language.

(Schüssler Fiorenza 1989:23)

Historical retelling formed part of a rhetorical argument to persuade the letter's recipients to agree with his position and to refuse the opponents' stance (apologetic rhetoric, Betz) or to decide to submit to Paul's understanding of the Gospel and the opponents' views (deliberative, Smit).

On the other hand, Galatians 4:21-5:1 forms part of what can be called Pauline historiography, in the sense of Paul's typical approach to and dealing with his (Israelite and Jewish) traditions. ${ }^{21}$ Galatians 4 therefore did not form part of Pauline history, 'the history according to Paul', in the sense of aspiring to provide a factual or other account of events that took place and not even his 'history writing' in the sense of consciously and deliberately engaging in the former. ${ }^{22}$ What further stands out in Pauline historiography is that in Galatians it was informed by the scriptures of Israel (Septuagint) and adjunct traditions. Or to put it the other way round, Pauline exegesis can be understood as rereading, that is, re-creating or re-writing or re-composing history. In other words, Paul was apparently not disputing the historical veracity of the events he mentioned, since the focus was hardly on accuracy in the modern sense. For Paul the actuality of the events took centrestage, stressing that the events took place, and in therefore, in Paul's book, they are historiographical. In one sense, Pauline exegesis is not about history at all; in another sense, it is all about his revisionist way of approaching ancient history.

The reciprocal relationship between textual composition and identity is particularly important in Galatians 4:21-5:1 and illustrates the involvement of texts in identity-making processes; Paul's text (Galatians), at the same time, reflects his identity but also constitutes and maintains (or co-constitutes) his reformulated identity in a dynamic (on-going) and complex (mutual but also difficult to pin down beginning and end, cause and effect) relationship.

21.The description of historiography 'as the written record of what is known of human lives and societies in the past and how historians have attempted to understand them' (Partner 2008:1 [author's emphasis], with the focus on the second part, is applicable here.

22.Three important aspects of the study of historical narrative include: (1) writing of history is always more and less than the past; (2) historiography account for the present to which the past has led and is thus a powerful instrument in community legitimation, identity formation and instruction; (3) in history or writing, events acquire narrative form (Green 2005:61-62). It is a modernist notion that history entailed access to events of the past and their chronological sequencing; in short, seeing history as intelligible structure populated by accumulated facts; so also is it a modernist idea that the historian is neutral, without bias or presupposition merely recording facts in the sense of objective reality. 


\section{Paul, identity and (new) community}

It was more than likely that Paul was a Jew from a Pharisaic background (Phlp 3:5; cf. Gl 1:14) and faced with the situation (at least in the communities where he worked) that Gentiles were increasingly becoming the majority amongst the followers of Jesus, often even in faith communities that initially consisted of Jewish followers of Jesus. He was hardpressed both to avoid two classes of followers of Jesus as well as to neutralise understandings of the implications of the Gospel that differed from his own. Addressing the Jewishand Gentile follower of Jesus from his own socio-religious framework, Paul occupied a moderate position and argued that the Gentiles had to be included in the community of the faithful through the model of the Noachian commandments, ${ }^{23}$ without specific Jewish rules and circumcision in particular (Segal 1995:20). Theologically Paul argued that all people sinned and are judged by the Law (Gl 2:15-21; cf. Rm 1:183:20) and therefore that repentance and faith are required of all people, Jews and Gentiles alike. As there are no separate covenants for Jews and Gentiles, ${ }^{24}$ all should meet the same standard, that is, transformation by faith in the risen, spiritual Christ. Gentile followers of Jesus are therefore to be treated as 'righteous Gentiles' and not as 'resident sojourners' - as equals. $^{25}$

Paul's primary concern with the newly formed communities of Christ-followers and their new identity in Christ meant a focus on transformation by faith that brings justification, a universal process for Jewish as well as Gentile converts to Christianity - not a critique of works-centred righteousness, an anxiety characteristic of a later time. ${ }^{26}$ Identification was both theologically and ethically oriented and interacted with two dominant symbols, cross and resurrection (Lampe 1995:931-943; cf. Verhey 1983:119) and was variously expressed as, for example, in prepositional phrases with бuv [with] or ' $\epsilon$ [in] and Christ. Such phrases provided the invitation for identification whilst the ethical dimension included the Pauline emphasis on love and edification instead of selfishness as well as patient and joyful endurance. ${ }^{27}$

23. Unlike the 'apostolic decree' as presented by Luke (Ac 15:20, 29; 21:25), which assumed the model of rules applicable to the sojourner (Segal 1995:13-20).

24.As, for example, Gaston (1987), Gager (1983) and, of course, Stendahl argue: 'for the Jews, salvation is on basis of the Law; for Jesus followers, salvation is on basis of Christ'. Bockmuehl (1995:100) contends that Paul attempted 'to forge a united body of Jewish and Gentile Christians in a fellowship of equals, in which the forme continue to live by the special laws and the latter merely by the Noachide laws'

25. Regarding the relation between practicing the Law and the salvation of the Gentiles, Paul's approach approximates other positions in Judaism. His emphasis on 'the centrality of faith, his insistence that all need transformation, and his specific language for flesh and spirit' are, however, different from the positions of other Hellenistic Jewish writers (Segal 1995:23)

26.Does 'fleshly and spiritual observances' amount to the 'ceremonial' and 'moral' law distinction? Along with Dunn, Segal holds that 'works of the Law' denotes the effects of ceremonial laws in the community, but adds that it refers to ceremonia laws as such, as well. Paul is saying that the special laws of Judaism are not relevant for salvation' (Segal 1995:23-24). The ceremonial Jewish laws are not nullified, but relativised by faith in Christ, are voluntary and valuable in as far as practicing them contributes to unity in the community. The supposed 'inconsistency' (Sanders) and 'incoherency' (Räisänen) of Paul's statements on the Law can thus be addressed: operating with a Noachian commandments-model, Paul 'is willing to accept some of the rules of the sojourner if that will achieve peace and unity within his community of Christians' (Segal 1995:26-27). Bockmuehl (1995:100) contends that Paul attempted 'to forge a united body of Jewish and Gentile Christians in a fellowship of equals, in which the former continue to live by the special laws and the latter merely by the Noachide laws'.

27.Paul's emphasis in Romans 6 and elsewhere on change in status, assumption of new roles and recreating identity recalls notions of 'rites of passage' or 'initiation'. For the interplay between baptism and the identity of the followers of Christ, cf., for example, Engberg-Pedersen (1995:502); Kysar (1991:74): 'The society of the church was a single, seamless fabric by virtue of its shared baptism in Christ'.
Such discourse not only created new relationships within the community but created a new sense of identity (Lampe 1995:940). ${ }^{28}$ In word and deed, through preaching and evangelising as well as in community practices, Paul's vision of a new, unified community of Jesus followers clearly emerged. The unified community was premised on the removal of ritual distinctions between Jew and Gentile in the Jesus followers-community..$^{29}$

The role of reinterpreted history in the negotiation of identity and identity formation ${ }^{30}$ is evident in Galatians 4:21-5:1, particularly in the use of scriptural interpretation to drive a wedge between groups.

\section{Insiders and outsiders: Community and identity}

Despite the difficulties involved, the identification of self and others in New Testament times was part of being a faith community built around core beliefs, regardless of the community's ability to maintain such beliefs or the level at which these are posed as normative. Such beliefs generally exude and even encourage a certain ethical practice. In the Old Testament, with its strong monotheistic stance and theocratic setting, the people of Israel not only identified themselves accordingly, but also identified other people in contrast to such claims and ideals. ${ }^{31}$ This was the case with early Christianity too, with (at times, diverse!) beliefs centring around Jesus Christ, accompanied by the promotion of a strong ethos in the nascent Christian communities. The resulting us-them perspective is found in various contexts in the New Testament and in all the major corpuses. In the Gospels it is the strong anti-Judaic tone which surfaces repeatedly, revealing two strata of the Jesus story. On one level, it is a relative simple story of Jesus that is primary, but amidst the reinterpretation of the events, which took place after his death, the story about him is told with the communities' concerns in mind. ${ }^{32}$ Early Christianity, at times, advanced the notion of inclusivity and claimed the universal

28.Psychoanalytically, the difference between one who imitates and one who identifies with the model person is that the latter not only displays similar behaviour but adopts the model person's motivations, goals and emotions, as well. This requires a 'libido impulse' or affection between Christ and believers and eventually leads to a radical restructuring of the Ego by identification with Christ', initiated by the ritual identification process of baptism (Lampe 1995:940).

29.In a related way, Paul's position also provides significant insights into the Jewish position(s) on universalism in the 1st century (Segal 1995:27-29). Both Judaism and Christianity under influence of the Hellenistic period and its dominant cultura forces, argued not just for universalism but also for the toleration of differences within monotheistic religion.

30.Compare also Swancutt's remarks on the close relationship between enculturation and imperialism, seen especially in education [ $\pi \alpha\llcorner\delta \in i \alpha]$ : 'Both Paul and his cohorts used the Jewish scriptures, in a Greco-Roman cultural environment and in a dialectical relationship with Greco-Roman educational practices, to teach and enculturate communities of ethnic Greeks in how to (be)come Israel' (Swancutt 2006:4)

31.The accuracy and legitimacy of such claims regarding self as well as regarding the Others is a discussion reserved for another time.

32.The Fourth Gospel expresses anger against Jews who became the symbol for all who rejected God (Jn 5:16; 8:57-59; 18:12; 19:10), in a context where the early might of the Roxt dion and the might of the Roman Empire to annihilate whole communities for dissent. Echoes fhe (1) Revelations 21 and 22 (Pippin 1992.55-56). In the Johannine letters the categories are starkly divided between the saved and the damned: cf. on Lieu insiders and outsiders in 2 and 3 John (1986:125-165; especially 145-148). 
impact of Jesus Christ, trimming down on religious ritual and entrance requirements, which could have posed barriers for new recruits. At the same time, from an early stage the New Testament documents also attest to identifying and allocating people into groups, underwriting such practices and their accompanying claims with both religious fervour and argument.

Paul's response to the recipients and indirectly his opponents in Galatia entailed a renewed focus on the primeval covenant, affording it an imperial-like nature. Without contrasting covenant to law, Paul set up a total divergence between two understandings of the covenant, built respectively on what he called the promise and the law. Whilst this respects the importance of the covenant for Jewish identity and selfdefinition, Paul emphasised a singular covenant deriving from (reliance on) the promise and not from (affiliation through) the law (cf. Dunn 1993:249). The covenant is therefore exclusive by nature and presupposes insiders and outsiders. However, whilst the covenant is exclusive it is not restricted or closed off: the choice of the (renewed) covenant $t^{33}$ is not for or against Jews, for or against Gentiles, but an inclusive choice for all people (cf. Park 2003); but (and this is important), such inclusion is according to the requirements according to Paul's understanding. ${ }^{34}$ The anomaloussounding inversion where Sarah's descendents according to the flesh are seen as the true descendents of Hagar and the descendents of Hagar according to the flesh are seen as the true descendents of the free Sarah, is assumed and implies an exclusionist interpretation (Tamez 2000:268-9).

\section{Hermeneutics, identity and power}

It is already clear that both revisionist hermeneutics and identity-advocacy entail the exercise of power, in the sense of assuming the right to challenge existing convention and custom but also in the sense of offering different, dissident and even subversive alternatives. But absolutist claims inevitably lead to rigid categories ${ }^{35}$ and strong boundaries have a way of calling out for their own protection, as well as for the custody of those inside. The New Testament authors with Paul in the lead, explicitly or otherwise, claimed a particular way to gain God's favour as described and prescribed by them. Dissent is outlawed, except for inconsequential matters and

33.The notion of a new or renewed covenant has antecedents in the Old Testament (OT) (cf. Jr 31:31-34) and is elsewhere used more extensively by Paul (e.g. the Corinthian correspondence)

34. Using the distinction between a toxic text which subjugates an authentic voice to a dominant story by claiming a superior validity and a revelatory tale which facilitate the discovery of a person or group's authentic story, Galatians 4:21-5:1 is a toxic text (Davis 2007:232-236). Whilst the 'Jerusalem above' (GI 4:26) refers to divine text (Davis 2007:232-236). Whilst the 'Jerusalem above' (GI 4:26) refers to divine
origin, this might not necessarily entail 'an invisible people, to whom all races origin, this might not necessarily entail an invisible people, to whom all races
belong in their diversity, who receive the logic of faith as the founding principle belong in their diversity, who receive the logic of faith as the founding principle
of their practices, attitudes, and relations in their own particular world' (cf. Park 2003).

35.Other binary opposites are found throughout the New Testament corpus, often playing on religious or spiritual distinctions and employing symbolic language, such as to be free or enslaved, children of the light or children of the darkness, the faithful or the apostates, those on the narrow or those on the broad way, the wheat or the chaff, the sheep or the goats, the strong or the weak. Suffice it to say that some opposites invoked sentiments that entail going beyond religious categories for explaining the force of the contrast and even the original identity-concerns and might be related to categories of privilege and marginalisation, wealth and poverty and other socio-political configurations. compromise unwarranted, especially in a world dominated by the struggle between evil and good forces where choices have to be made and double allegiances are not tolerated. The grouping of humanity in camps necessarily gave rise to (mutual) exclusion and depending on control over power and ideology, also marginalisation.

Paul's hermeneutical efforts jeopardised Jewish identity without suggesting that this was a monolithic entity in the 1st century CE - when he reduced the ethnic as well as spiritual link Jews treasured with Sarah, wife of Abraham, to spiritual lineage only (cf. Osiek 1998:426; cf. Boyarin 1994). The sociopolitical setting of Paul's interpretations is important for understanding how Paul put the Hagar or Sarah narrative to use allegorically. ${ }^{36}$ The end result is, though, that Paul transposes $^{37}$ traditional interpretation, although in later Pauline interpretation his original internal Jewish polemics became part of Christian Empire and its anti-Judaism..$^{38}$ Amidst the ambivalence that a reworking of the history of Abraham and his progeny implied, in Galatians Paul's redeployment of the narrative of Abraham's wives and sons according to a spiritual lineage rather than biological line, implicitly challenged the Roman Empire through his (Paul's)

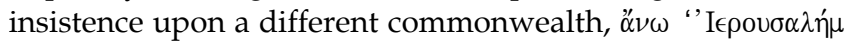
([Jerusalem above], 4:26; cf. Phlp 1:27, 3:20). ${ }^{39}$

On the one hand Sarah as historical figure and her legacy was subverted, and the link between her and the (largest part of the) Jewish nation severed. On the other hand, and at the same time Sarah, at least momentarily, was used to subvert Abraham, when she became the primary reference point for the faithful! In Galatians 4:30 Paul completed the logic of his argument regarding the two wives of Abraham and in particular his consistent emphasis on being aligned with Sarah as the free woman and with her legacy. But of all the displacements in and around the text, Sarah's words which ring through the Galatian community are clearest in justifying the exclusion of those who differed from Paul and his perception of the truth of the gospel. In the momentary reversal of gender roles, with a woman determining the course of events in a patriarchal context, the stabilisation of conventional gender patterns is nevertheless ensured: the harsh words that excludes and marginalises belong to a woman!

\section{Power, stereotyping, slander and vilification}

The harsh environment of the 1st century $\mathrm{CE}$, with its

36.Space does not allow for discussing the interesting further developments resulting from the influence of particular social locations in the history of Pauline interpretation - such as slavery during colonial times - on the understanding of Sarah and her actions (cf. Schneider 2004:133). Compare Briggs (2000:110-123) and Kwok (2005:87) on the confluence between slavery and gender and how it plays out in the retold Sarah or Hagar narrative in Galatians 4

37.The scriptures of Israel are testimony of Israel becoming like Hagar, 'enslaved in a foreign nation, cries out in pain, and escapes to the wilderness' ( $O$ 'Conno 1997:31). In terms of the link between category distinctions and socio-politica discrimination, cf. Eiser (1996:139). Here we find early signs how Paul formulated a religious discourse: 'Successful formation of a religious discourse was one of early Christianity's greatest strengths. This is precisely what both Paul and Augustus recognized' (Cameron 1991:42).

38. Refer to Söding (2007:237) on the danger of reading Galatians 4:21-5:1 through Christian supersessionist glasses and implications for understanding the position of Jews and the Law.

39.Compare also the next section for the significance of Galatians 6:16 and the renewed commonwealth of Israel in this regard - cf. Swancutt (2006:4). 
agonistic society incorporated a values-subtext, which was informed by attempts to increase honour and elude shame. Society was not only informed by and structured according to various hierarchies, it was patriarchy in particular that defined and inscribed male power and dominance. In a collectivist society and a context often characterised by pessimism and hopelessness, people dealt with each other and with foreigners in particular in terms of stereotype and slander (Malina and Neyrey 1996:169-174), often amounting to vilification. In a recent monograph (Knust 2006), it is shown how sexual slander, for example, also amounted to invented categories of social identity and attempts at exercising control (cf. Frankfurter 2005:143).

Not only hermeneutics or the interpretation of the tradition but also the ability to exercise influence over the construction of identity, implicates authors in matters of power and therefore reflects their power; particularly in the case where such interpretations and identity-constructions are accepted. Given the situation in the New Testament, Paul acquired the power to exercise authority in the construction of identity. The social location of the Galatian recipients and even of Paul as author needing to reassert his authority, did not permit a conciliatory stance from his perspective, least of all to promote an accommodating stance within the social context within which the recipients of the letter found themselves. ${ }^{40}$ To the contrary, amidst the slander and vilifying of his opponents as 'foolish' or 'idiot ${ }^{41}$ Galatians' (e.g. Gl 3:1; cf. 5:15) in what appears as harsh or even rude (and certainly sarcastic ${ }^{42}$ ) terms, suggesting for example, that they should consider castration given their penchant for circumcision (e.g. cf. Gl $5: 12),{ }^{43}$ the ideological setting of Galatians was characterised by Paul's rhetorical pitch. This was no negotiated settlement but an argument that had to be won and the battle lines were drawn around the interpretation of the narratives of origin, the genealogical wherewithal of the faithfulness of God. Notwithstanding the insistence that neither the presence nor the absence of circumcision alone amount to anything (6:16), it is significant that Paul concluded in Galatians 6:16, using a scriptural phrase, 'peace on Israel' (Ps 125:5; 128:6). Read through the lens of Isaiah 54:10 LXX, this benediction appears to confirm that all who belong to the new (renewed) order constitutes the new (renewed) or eschatological people of God (cf. Silva 2007:810). ${ }^{44}$

40.Tajfel on categorising or stereotyping: 'Stereotypes were held and shared by people as members of social groups and reflected the nature of intergroup relations. They had social as well as individual functions; in particular they provided group members with positively valued intergroup differences which enhanced their socia identity, and explained and justified intergroup relations. They served collective (a) (Turner 1996a:14).

41.Paul's reproach in Galatians 3:1 was directed at the community, whom he insulted through equating them to the Celtic inhabitants of the north who had a insulted through equating them to the Celtic inhabitants of the north who had a reputation throughout antiquity for having
simpleminded people (Mitchell 1992:872).

42.'Tajfel's simple but stunning insight was that even the most trivial of category distinction can be the cue for the most extreme forms of discrimination' (Eiser 1996:139).

43.The hint at castration can probably be read along with the further sexual innuendo in Galatians 5:24 (cf. Gal 5:16-26) which played on the sexual stereotype of Gentile sexual perversion and deviance. When addressing circumcision in Phlp 3:2-4a, Paul also warned against the 'mutilation' ( $\tau \dot{\eta} \nu \kappa \alpha \tau \alpha \tau o \mu \eta \dot{v}$ ['those who mutilate the flesh]', NRSV, Phlp 3:2).

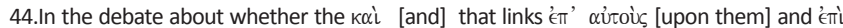

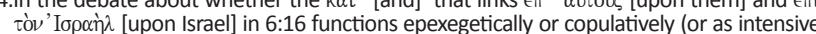

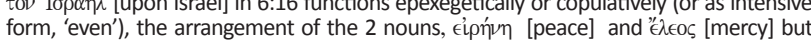
above all, the sense of the letter seems to suggest that an epexegetical understanding above all, the sense of the letter seems to suggest that an epexegetical understanding
is more appropriate here. Longenecker (1990:197-219) who admits that the question of who should

\section{Conclusion}

Some related concerns could not be addressed here and include how Paul achieved the position whereby he was capable of reconfiguring identity; a detailed investigation of the structure and contents of what constituted his discourse of identity formulation; identifying the elements which constituted and secured his power to enact such a discourse and, to investigate the reasons why his (powerful) discourse (of power) remained in place during his lifetime (even after his death). It is also important to trace the relationship between the textual traditions of interpreting Paul's texts, as they were elaborated upon after his death, for example, in Ephesians, Colossians, 2 Thessalonians and the Pastoral Epistles, and identity issues. Identity formation within intentional communities where group consciousness implies boundaries creates insiders and outsider, with marginalised groups claiming their detrimental status as both an indication of their special status before God and as a warrant for venting anger and violence on their opponents and rest of society in general, also deserves more study (cf. Selengut 2003:85).

Given the volatile and fragile nature of identity in the changing 1st century environment, defining communal identity was a precarious undertaking. In Galatians Paul made use of the scriptures of Israel and the Abraham narrative in particular to strengthen his appeal for a certain identity, both in its understanding and practice. Interpreting the scriptures and the history of Israel in a certain way was evidently not merely an element of identity, but stood in a reciprocal relationship with defining identity, because these and other processes of defining identity that Paul engaged in gave rise to a certain interpretation of the scriptures and history, as much as his rereading facilitated a certain sense of identity - and its promotion.

The reading and rereading of texts of course did not come to an end in New Testament times, nor has the relationship between text and identity, or the role of hermeneutics in the formation of identity ceased to exist with the final formation of the New Testament. ${ }^{45}$ The link between the scriptures and the sense of identity suggests that 'enscripturalised identity' may be a useful concept to describe self-definition but also the identification of the other through the interpretation and appropriation of the biblical texts, ${ }^{46}$ in the past but also today. Regardless of nomenclature, Paul's letters provide a

(Footnote 44 cont...)

be considered children of Abraham is central to the Galatian letter and rightly dismisses a Christian church versus Jewish nation contrast, unfortunately does not seem to allow for a broader understanding of Israel, incorporating also Gentiles when physicality is no longer the determinative feature for belonging or identity.

45.In fact, regarding the way that Sarah has been perceived in the Christian communities of later years, 'The New Testament supplies several proof texts that the Christian community has used to shape its understanding of Sarah and her character' (Schneider 2004:131; Punt 2007:453-478). Schneider (2004:124-133) argues that the New Testament is prominently responsible for a prejudiced reading argues that the New Testament is prominently responsible for a prejudiced reading
of Sarah, in contrast to her portrayal in Genesis; on the other hand she admits to both not being a 'specialist in the New Testament' and coming to 'preliminary' conclusions after taking the New Testament 'at face value'.

46.Identities of the self and other are, amongst others, textually enscribed. The relation between hermeneutical processes of identity and othering and social identity and othering is worth noting, especially against the background of a pragmatist or interpersonal reading perspective: hermeneutical and social a pragmatist or interpersonal reading perspective
'otherness' is interrelated. Compare Punt (2002). 
first glimpse in the New Testament of a dynamic, reciprocal relationship between hermeneutics and identity and probably also their function as building blocks for (eventually) Christian communities to become scriptural communities. ${ }^{47}$

\section{Acknowledgement}

It is a privilege to contribute an article in honour of a much appreciated colleague in New Testament Studies, Prof. Andries G. van Aarde - he has been and continues to be an inspiration in the scholarly community in southern Africa in particular, often challenging conventional thinking and always keen and eager to share ideas and learn from others.

\section{References}

Berger, K., 2003, Identity and Experience in the New Testament, transl. C. Muenchow, Fortress, Minneapolis.

Bij de Vaate, A.J. \& Van Henten, J.W., 1996, 'Jewish or Non-Jewish? Some Remarks on the Identification of Jewish Inscriptions from Asia Minor', Bibliotheca Orientalis 53(1-2), 16-28.

Bockmuehl, M., 1995, 'The Noachide Commandments and New Testament Ethics. With Special Reference to Acts 15 and Pauline Halakah', Revue Biblique 102(1), 72-101.

Botha, P.J.J., 2000, 'Submission and violence: Exploring gender relations in the firstcentury world', Neotestamentica 34(1), 1-38.

Boyarin, D., 1994, A Radical Jew. Paul and the Politics of Identity, Critical Studies in Jewish Literature, Culture, and Society, vol. 1, University of California Press, Berkeley.

Briggs, S., 2000, 'Paul on Bondage and Freedom in Imperial Roman Society', in R.A. Horsley (ed.), Paul and Politics. Ekklesia, Israel, Imperium, Interpretation. Essays in Honor of Krister Stendahl, pp. 110-23, Trinity Press International, Harrisville.

Cameron, A., 1991, Christianity and the Rhetoric of Empire. The Development of Christian Discourse, University of California Press, Berkeley.

Dahl, N.A., 1977, Studies in Paul. Theology for the Early Christian Mission, Augsburg, Minneapolis.

Davis III, C.T., 2007, 'Defining a Toxic Text', in W.G. Rollins \& D.A. Kille (eds.) Psychological Insight into the Bible. Texts and Readings, pp. 232-236, Eerdmans, Grand Rapids.

Deschamps, J., 1982, 'Social Identity and Relations of Power between Groups', in H Tajfel (ed.), Social Identity and Intergroup Relations, pp. 85-98, European Studies in Social Psychology, Cambridge University Press, Cambridge.

Desjardins, M., 1997, Peace, violence and the New Testament, Sheffield Academic Press, Sheffield.

Dunn, J.D.G., 1988, Romans 9-16. Vol 38b. Word Biblical Commentary, Word Books, Dallas.

Dunn, J.D.G., 1990, Jesus, Paul, and the Law. Studies in Mark and Galatians, WJK, Louisville.

Dunn, J.D.G., 1993, The epistle to the Galatians, Black's NT Commentaries, Hendrickson, Peabody.

Ebeling, G., 1985, The truth of the Gospel. An exposition of Galatians, transl. T.D. Green, Fortress, Philadelphia.

Eiser, J.R., 1996, 'Accentuation revisited', in W.P. Robinson (ed.), Social Groups and Identities. Developing the Legacy of Henri Tajfel, pp. 121-42, International Series in Social Psychology, Butterworth, Heinemann, Oxford.

Engberg-Pedersen, T., 1995, 'Galatians in Romans 5-8 and Paul's Construction of the Identity of Christ Believers', in T. Fornberg \& D. Hellholm (eds.), Texts and Contexts. Biblical Texts in their Textual and Situational Contexts. Essays in Honor of Lars Hartman, pp. 477-506, Scandinavian University Press, Oslo.

Fowl, S.E., 1994, 'Who can read Abraham's story? Allegory and interpretive power in Galatians', Journal for the Study of the New Testament 55, 77-95.

Frankfurter, D., 2005, 'Violence and Religious Formation: An Afterword', in S. Matthews \& E.L. Gibson (eds.), Violence in the New Testament, pp. 140-152, T \& T Clark International, New York, London.

Gager, J., 1983, The Origins of Anti-Semitism: Attitudes towards Judaism in Pagan and Christian Antiquity, Oxford University Press, New York.

47. Unlike a textual community with its focus on written texts, a scriptural community shifts the emphasis to scripture, which is often, but not exclusively, inscribed textually: the textual aspect is incidental to the scriptural, that is the foundational tradition. 'What distinguishes a textual community from an aural/ora coununity is a worldiew shift, wherishy community is a worldview shift, whereby texts become privileged sites of fact and comm communities, like textual communities primacy, and constitutive characte' of the community's sense of scripture can be corrupted or diminished. In scriptural communities also, 'The most threatening kind of otherness, [is] the otherness within' (Green 1985:69).
Gaston, L., 1987, Paul and the Torah, University of British Columbia Press, Vancouver. Georgi, D., 1991, Theocracy in Paul's Praxis and Theology, transl. D.E. Green, Fortress, Minneapolis.

Georgi, D., 1992, Remembering the Poor: The History of Paul's Collection for Jerusalem, transl. I. Racz, Abingdon, Nashville.

Green, W.S., 1985, 'Otherness within: Towards a Theory of Difference in Rabbinic Judaism', in J. Neusner \& E.S. Frerichs (eds.), "To See Ourselves as Others See Us": Christians, Jews, "Others" in Late Antiquity, pp. 49-69, Scholars, Chico.

Green, J.B., 2005, 'Learning Theological Interpretation from Luke', in C. Bartholomew, J.B. Green \& A.C. Thiselton (eds.), Reading Luke. Interpretation, Reflection,
Formation, pp. 55-78, Scripture and Hermeneutics Series, vol. 6, Zondervan, Paternoster, Grand Rapids.

Hays, R.B., 1996, The Moral Vision of the New Testament. A Contemporary Introduction to New Testament Ethics, HarperSanFrancisco, San Francisco.

Hogg, M.A., 1996, 'Intragroup Processes, Group Structure and Social Identity', in W.P. Robinson (ed.), Social Groups and Identities. Developing the Legacy of Henri Tajfel, pp. 65-93, International Series in Social Psychology, Butterworth, Heinemann, Oxford.

Janzen, J.G., 1991, 'Hagar in Paul's eyes and the eyes of Yahweh (Genesis 16): A study in horizons', Horizons 13(1), 1-22.

Jobes, K.H., 1993, 'Jerusalem, our mother: Metalepsis and intertextuality in Galatians 4:21-31', Westminster Theological Journal 55(2), 299-320.

Kelso, J., 2008, 'Us versus them', The Bible and Critical Theory 4(1), 1.1-1.4. doi: $10.2014 /$ bc080001

Knust, J.W., 2006, Abandoned to Lust. Sexual Slander and Ancient Christianity, Gender Theory, and Religion, Columbia University Press, New York.

Kysar, R., 1991, Called to Care. Biblical Images for Social Ministry, Fortress, Minneapolis.

Kwok, P., 1995, 'Discovering the Bible in the Non-Biblical World, The Bible \& Liberation Series', in N.K. Gottwald \& R.A. Horsley (eds.), n.p., Orbis, Maryknoll.

Lampe, P., 1995, 'Identification with Christ. A Psychological View of Pauline Theology', in T. Fornberg \& D. Hellholm (eds.), Texts and Contexts. Biblical Texts in their Textual and Situational Contexts. Essays in Honor of Lars Hartman (eds.), pp. 930-943, Scandinavian University Press, Oslo.

Lieu, J.M., 1986, The Second and Third Epistles of John: History and background, Studies of the New Testament and its world, T \& T Clark, Edinburgh.

Longenecker, R.N., 1990, Galatians, Word Biblical Commentary, vol. 41, Word, Dallas.

Malina, B.J. \& Neyrey, J.H., 1996, Portraits of Paul: An Archaeology of Ancient Personality, Westminster John Knox, Louisville.

Martin, L.H., 1994, 'The Anti-Individualistic Ideology of Hellenistic Culture', Numen 41(2), 117-140. doi: 10.2307/3270256

Martyn, J.L., 1990, 'The Covenants of Hagar and Sarah, in J.T. Carroll, C.H. Cosgrove \& E.E. Johnson (eds.), Faith and History: Essays in Honor of Paul W Meyer, pp. 160-192, Scholars, Atlanta.

Mitchell, S., 1992, sv 'Galatia (Place)', in D.E. Freedman (ed.), Anchor Bible Dictionary, vol. 2 (D-G), pp. 872-875, Doubleday, New York.

Neyrey, J.H., 1993, 'Dyadism', in J.J. Pilch \& B.J. Malina (eds.), Biblical social values and their meaning. A handbook, pp. 49-52, Hendrickson, Peabody.

O'Connor, K.M., 1997, 'Abraham's Unholy Family: Mirror, Witness, Summons', Journal for Preachers 21(1), 26-34.

Osiek, C., 1998, 'Galatians', in C.A. Newsom \& S.H. Ringe (eds.), Women's Bible commentary, exp.edn., pp. 423-427, WJK, Louisville.

Park, E.C., 2003, Either Jew or Gentile. Paul's Unfolding Theology of Inclusivity Westminster John Knox, Louisville.

Partner, N.F., 2008, Historiography (Concordia University, Wisconsin) viewed 13 February 2008, from http://www.cuw.edu/Academics/programs/history/ historiography

Pilch, J.J., 1993, 'Power', in J.J. Pilch \& B.J. Malina (ed.), Biblical social values and their meaning. A handbook, pp. 139-142, Hendrickson, Peabody.

Pippin, T., 1992, Death and desire. The rhetoric of gender in the Apocalypse of John, Literary Currents in Biblical Interpretation, WJK, Louisville.

Punt, J., 1996, 'Paul, Hermeneutics and the Scriptures of Israel', Neotestamentica 30(2), 377-425

Punt, J., 2002, 'Enscripturalised identity: Scripture and identity in Christian communities', Nederduits Gereformeerde Teologiese Tydskrif 43 (1\&2), 83-93.

Punt, J., 2006a, 'Revealing rereading. Part 1: Pauline allegory in Galatians 4:21-5:1', Neotestamentica 40(1), 87-100.

Punt, J., 2006b, 'Revealing rereading. Part 2: Paul and the wives of the father of faith in Galatians 4:21-5:1', Neotestamentica 40(1), 101-118.

Punt, J., 2007, 'Subverting Sarah in the New Testament: Galatians 4 and 1 Peter 3', Scriptura 96, 453-468.

Schneider, T.J., 2004, Sarah. Mother of Nations, Continuum, New York \& London.

Schüssler Fiorenza, E., 1989, 'Text and Reality - Reality as Text: The Problem of a Feminist Historical and Social Reconstruction Based on Texts', Studia Theologica 43(1), 19-34. doi: 10.1080/00393388908600063

Segal, A.F., 1995, 'Universalism in Judaism and Christianity', in T. Engberg-Pedersen (ed.), Paul in His Hellenistic Context, pp. 1-29, Fortress, Minneapolis.

Selengut, C., 2003, Sacred fury. Understanding religious violence, AltaMira, Walnut Creek. 
Silva, M., 2007, 'Galatians', in G.K. Beale \& D.A. Carson (eds.), Commentary on the New Testament Use of the Old Testament, pp. 785-812, Grand Rapids, Nottingham, Baker Academic, Apollos.

Soards, M.L., 1999, 'The life and writings of Paul', in M.A. Powell (ed.), The New Testament today, pp. 86-99, WJK, Louisville.

Söding, T., 2007, "Sie is unsere Mutter". Die Allegorie über Sara und Hagar (Gal 4,21-31) in der Einheitsübersetzung und bei Paulus', in C. Dohmen \& C. Frevel (Hrsg.), Für Immer Verbündet. Studien zur Bundestheologie der Bibel, Stuttgarter Bibelstudien, vol. 211, n.p., Verlag Katolisches Bibelwerk GmbH, Stuttgart.

Stanley, C.D., 2004, Arguing with Scripture. The rhetoric of quotations in the letters of Paul, T\&T Clark, New York.

Swancutt, D.A., 2006, 'Scripture "reading" and identity formation in Paul. Paideia among believing Greeks', paper presented at the 2006 Paul and Scripture Seminar, SBL Annual Meeting, Washington DC, November 2006, viewed n.d., from http://www.westmont.edu/ fisk/paulandscripture/ SwancuttScriptureAndIdentityFormationInPaul.pdf

Tajfel, H., 1982a, 'Instrumentality, Identity and Social Comparisons', in H. Tajfel (ed.) Social Identity and Intergroup Relations, pp. 483-507, European Studies in Socia Psychology, Cambridge University Press, Cambridge.

Tajfel, H., 1982b, 'Introduction', in H. Tajfel (ed.), Social Identity and Intergroup Relations, pp. 1-11, European Studies in Social Psychology, Cambridge University Press, Cambridge.
Tamez, E., 2000, 'Hagar and Sarah in Galatians: A case study in freedom', Word \& World 20(3), 265-271.

Turner, J.C., 1982, 'Towards a Cognitive Redefinition of the Social Group', in H. Tajfe (ed.), Social Identity and Intergroup Relations, pp. 15-40, European Studies in Social Psychology, Cambridge University Press, Cambridge.

Turner, J.C., 1996a, 'Henri Tajfel: An Introduction', in W.P. Robinson (ed.), Social Groups and Identities. Developing the Legacy of Henri Tajfel, pp. 1-23, International Series in Social Psychology, Butterworth, Heinemann, Oxford.

Turner, J.C., 1996b, 'Social Identity, Interdependence and the Social Group: A Reply to Rabbie et al', in W.P. Robinson (ed.), Social Groups and Identities. Developing the Legacy of Henri Tajfel, pp. 25-63, International Series in Social Psychology, Butterworth, Heinemann, Oxford.

Verhey, A., 1984, The Great Reversal. Ethics and the New Testament, Eerdmans, Grand Rapids.

Volf, M., 1996, Exclusion and Embrace. A Theological Exploration of Identity, Otherness, and Reconciliation, Abingdon, Nashville.

Wenham, G.J., 1994, Genesis 16-50, vol. 2, Word Biblical Commentary, Word, Dallas.

Wilson, S.G., 1992, s v 'Jewish Christian Relations 70-170 CE', in D.E. Freedman (ed.) Anchor Bible Dictionary, vol. 3 (H-J), pp. 834-839, Doubleday, New York. 